\title{
Sistem Pemantauan Ban Hasil Inspeksi di Area Karantina OEM Berbasis VB.Net 2013
}

\author{
${ }^{1}$ Rifki Ridho Dwi Saputro, ${ }^{2}$ Muhammad Ridwan Arif Cahyono \\ 1,2Program Studi Teknik Elektronika Politeknik Gajah Tunggal

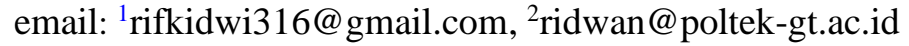

\begin{abstract}
Abstrak
Karantina Original Equipment Manufacture (OEM) merupakan sebuah bagian yang masih dalam satu lingkup dengan departemen Final Inspection, dimana bagian tersebut bertugas melakukan second inspection terhadap ban yang dikategorikan sebagai ban OE hasil dari pengecekan Dynamic Balance (DB) dan Uniformity (UF). Kesulitan yang dihadapi oleh inspektor di area karantina OEM yakni sulitnya melakukan monitoring tyre secara realtime. Kemudian kesulitan yang juga dihadapi oleh admin di departemen Final Inspection yakni sulitnya memproses data hasil check yang akan di proses menjadi report. Maka pada penelitian ini membuat sebuah sistem monitoring tyre berbasis VB.Net 2013 yang memepermudah inspekor dalam melakukan monitoring tyre dan mempermudah admin dalam memproses report hasil check. Untuk melakukan monitoring tyre inspektor dapat login di aplikasi monitoring tyre. Kemudian admin juga dapat memproses report hasil check hanya dengan 5 langkah yang menghabiskan waktu 5 hingga 7 menit saja.
\end{abstract}

Kata kunci: PHP, Vb.Net, Original Equipment Manufacture

\begin{abstract}
Quarantine Original Equipment Manufacture (OEM) is a part that is still within the scope of the Final Inspection department, where this section is tasked with conducting a second inspection of tires categorized as $O E$ tires resulting from Dynamic Balance (DB) and Uniformity (UF) checks. The difficulty faced by inspectors in OEM quarantine areas is the difficulty of monitoring tires in real time. Then the difficulties faced by admins in the Final Inspection department are the difficulty of processing the data from the checks that will be processed into reports. So in this study, a tire monitoring system based on VB.Net 2013 makes it easier for inspectors to monitor tires and make it easier for admins to process check reports. To do tire monitoring, inspectors can log in to the tire monitoring application. Then the admin can also process the check report with only 5 steps that take 5 to 7 minutes.
\end{abstract}

Keyword: PHP, Vb.Net, Original Equipment Manufacture

\section{Pendahuluan}

Industri manufaktur dalam menjalankan proses produksinya juga membutuhkan suatu sistem yang dapat memantau maupun menyimpan hasil produksi secara historis agar data-data tersebut dapat terhimpun dengan baik, serta dapat ditelusuri kembali di kemudian hari. Penelitian kali ini, dilakukan di area karantina Original Equipment Manufacture (OEM). Karantina Original Equipment Manufacture (OEM) merupakan section yang masih satu lingkup dengan departemen Final Inspection, yang mana tugas utamanya yakni melakukan pengecekan ban setelah proses Dynamic Balance dan Uniformity. Atau dapat disebut juga sebagai tempat dilakukannya second inspection terhadap appearance ban. Output yang dihasilkan dari proses di area Karantina OEM ini yakni ban yang masuk dalam kategori OE. Ban tersebutlah yang memenuhi syarat sebagai ban dengan hasil produksi terbaik. Ban dengan kategori OE akan di supply ke beberapa pabrik mobil. Namun di area karantina OEM terdapat isu masalah yakni 
sulitnya memantau jumlah ban yang masuk ke area karantina OEM dan memproses report data hasil pencapaian check ban di area karantina OEM. Hal tersebut didukung oleh data yang dihimpun melalui kuisioner dan disajikan dalam bentuk grafik berikut :

SULITNYA INSPEKTOR MEMONITORING HASIL CHECK)

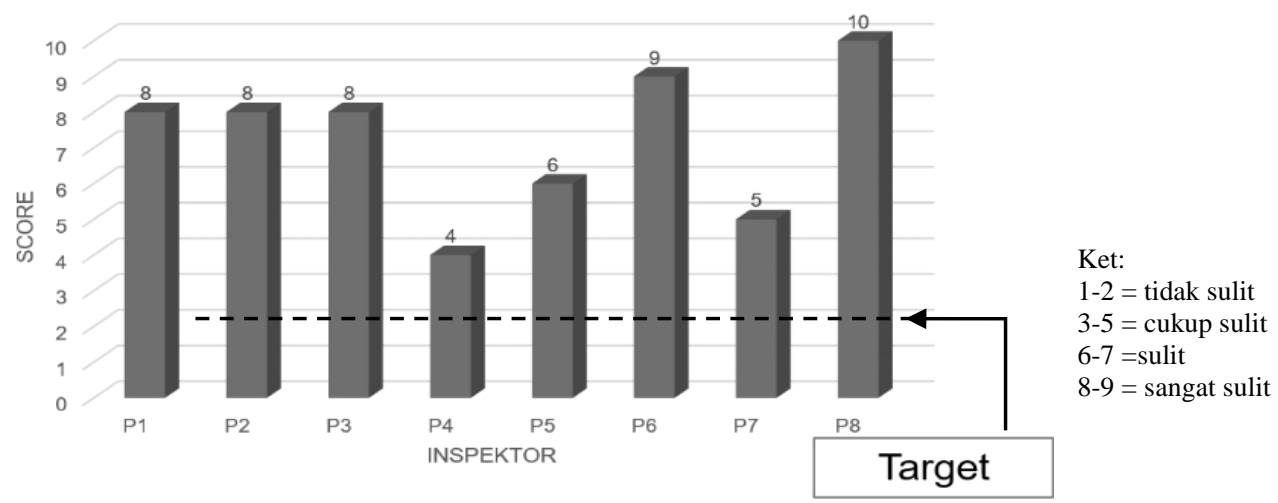

Gambar 1. Grafik Kuisioner Inspektor

Grafik diatas menggambarkan tingkat kesulitan yang di hadapi oleh inspektor untuk melakukan monitoring jumlah ban serta hasil check di area karantina OEM. Sebanyak 6 inspektor yang memberikan nilai diatas 5 yang mana itu mejadi indikasi sulitnya inspektor melakukan monitorig hasil check. Kondisinya saat ini, data hasil pengecekan per kategori ban masih terpisah. Untuk menyiasatinya, di area karantina OEM dibekali dengan report harian yang ditulis pada buku secara manual oleh inspektor dan dicatat di akhir shift.

Kemudian kondisinya saat ini pada sistem yang ada, data ban dengan kategori OE, OK, NG masih terpisah, hal tersebut disebabkan belum tersentralisasinya data yang dihimpun di aplikasi barcode. Untuk menghimpun data ketiga kategori ban tersebut seorang admin harus melakukan penarikan data sebanyak 3 kali dan mengolahnya. Hal tersebut menjadi tidak efisien dan membutuhkan waktu yang tidak sebentar. Untuk memproses data tersebut hingga menjadi data report hasil check membutuhkan setidaknya 14 langkah. Maka pada penelitian kali ini akan membuat sistem aplikasi dengan memanfaatka bahasa pemorgraman visual basic.Net. Aplikasi tersebut yakni aplikasi monitoring tyre dimana data ban dengan kategori OE,OK,NG sudah tersentralisasi dan membutuhkan 5 langkah saja untuk memproses report hasil inspeksi.

Pada penelitian sebelumnya dengan judul Rancang Bangun Prototype Sistem Monitoring Level Air Untuk Mendeteksi Banjir Berbasis Mikrokontroler Arduino Dan Visual Basic.Net. Hasil kajian yang diperoleh dari penelitian tersebut adalah membuat sistem yang dapat mendeteksi tinggi permukaan air sehingga volume air yang meningkat dapat diketahui. Sistem aplikasi monitoring tersebut dibuat menggunakan visual basic.Net [1]. Terdapat pula penelitian dengan judul Perancangan Sistem Monitoring Suhu Dan Kadar Air Pakan Ikan Pada Purwarupa Pengering Pakan Ikan Menggunakan Visual Studio. Hasil dari kajian tersebut yakni sistem aplikasi dengan visual studio yang bertujuan melakukan pemantaun suhu dan kadar air pakan ikan. Dimana Hasil pengujian monitoring suhu dan kadar air pakan ikan pada purwarupa pengering pakan ikan melalui LCD dan form Visual Studio berhasil berjalan dengan baik dengan jeda waktu pembacaan melalui Visual Studio sebesar 1 detik. Pengujian alarm pakan siap telah berhasil dilakukan ketika kelembaban mencapai 10\%RH dan kadar air sebesar $10 \%$ [2].

\section{Metode Penelitian}

Ada 3 metode yang digunakan yaitu metode pengumpulan data, metode perancangan dan metode pengujian.

\subsection{Lokasi dan Waktu}

Penelitian dilakukan di departemen Final Inspection selama lima bulan mulai Maret 
2021 s.d. Juli 2021.

\subsection{Pengumpulan Data}

1. Observasi

Mengamati proses kerja yang dilakukan inspektor di area karantina OEM.

2. Wawancara (Interview)

Mewawancarai inspektor dan admin sebagai user terkait sistem yang dibutuhkan

3. Kuisioner

Memberikan lembaran kuisioner sebagai media pendataan tingkat kebutuhan sistem yang akan dibuat dengan kondisi yang ada.

4. Studi Pustaka (Library Research) Mengumpulkan data-data dengan membaca bukubuku,artikel, jurnal ilmiah, dan website terkait perancangan absensi berbasis web.

\subsection{Metode Perancangan}

Metode perancangan yang digunakanpada penelitian ini menggunakan Unified Modelling Language (UML). Dimana UML merupakan visualisasi konsep dasar dari sebuah sistem yang akan dibangun.

\subsection{Literature Review}

Penelitian yang dilakukan oleh Samsir (2020) yang berjudul "Rancang Bangun Aplikasi Suku Cadang Pada Toko Urip Motor Menggunakan VB.Net 2010“. Pada toko Urip Motor proses pendataan penjualan suku cadang serta layanan meliputi interaksi antara perusahaan dan pelanggan perlu di lakukan pendataan dengan baik. Namun, masalah yang ada proses pencatatan tersebut cukup memakan waktu lama, sehingga membuat pelanggan menunggu. Solusi yang dilakukan untuk menangani masalah tersebut yakni membuat sistem otomatisasi interaksi pelanggan dengan toko dengan merancang dan membangun sistem aplikasi pencatatan penjualan suku cadang, pelayanan, serta stok barang toko Urip Motor. Aplikasi yang dibuat menghasilkan laporan penjualan stok barang, barang masuk, barang keluar, yang dilengkapi dengan database sehingga data barang tersimpan secara baik dan terstruktur di sistem komputer. Aplikasi yang dibuat yakni menggunakan bahasa pemrograman VB.Net dengan software Microsoft Visual Studio 2010 [3].

Penelitian yang dilakukan oleh Ranti Eka Putri dan Randi Rian Putra (2018) yang berjudul "Perancangan Apalikasi Rekam Medis Menggunakan Bahasa Pemrograman VB.Net 2010". Pada penelitian tersebut dimaksudkan untuk mempermudah pihak puskesmas dalam melakukan pencarian data pasien yang tergolong dalam pasien bpjs maupun pasien umum dilengkapi dengan riwayat penyakit pasien yang telah terintegrasi dengan database. Pada penelitian dan pengujian sistem dilakukan dengan penelitian lapangan atau observasi, tinjauan pustaka, dan penelitian laboratorium. Sehingga diketahui mekanisme kerja sistem yang ada. Sistem yang dibuat pada penelitian ini yakni menggunakan bahasa pemrograman VB.Net dengan software Microsoft Visual Studio 2010 [4].

Penelitian selanjutnya yang dilakukan oleh Iwan Fitriady Mukhlis (2020) yang berjudul "Rancang Bangun Peniliaian Barang Bergerak Pada Kantor Pt.Mandiri Finance Menggunakan Visual Studio 2020". Pada penelitian tersebut terdapat masalah yakni terdapat kemungkinan kesalahan dalam hal memasukan data atau perhitungan terhadap proses penilian properti. Maka pada penelitian tersebut dibuatlah sebuah sistem aplikasi perhitungan dan pemrosesan data dengan memanfaatkan bahasa pemrograman visual studio 2010. Dengan aplikasi tersebut karyawan dapat melakukan pemrosesan data dan penilaian barang bergerak lebih mudah dan efisien serta pembuatan laporan hasil penilaian dapat dilakukan lebih efektif [5].

\subsection{Tinjauan Pustaka}

\subsubsection{Definisi Monitoring}

Monitoring merupakan suatu kegiatan pemantauan secara berkala dengan periode tertentu kepada suatu objek dengan maksud untuk mendapatkan informasi dari objek yang dipantau. Monitoring juga merupakan kegiatan yang secara periodik, terstruktur dan terencana dengan cara melihat, mendengar, mencatat kondisi perkembangan objek. Kegiatan monitoring 
dilakukan sebagai cara suatu kelompok mengetahui perkembangan kondisi suatu objek yang dipantau dengan harapan mendapatkan data aktual dan digunakan sebagai media evaluasi dan peningkatan kinerja [6].

\subsubsection{Definisi Tyre Kategori}

Dalam praktiknya hasil produksi yang berupa ban tidak seluruhnya menjadi ban dengan kualitas yang baik. Terdapat seleksi kualitas dari segi appearance, keseragaman, serta keseimbangan ban. Apabila dari tiga aspek tersebut suatu ban memenuhi standart maka dapat dipastikan ban tersebut menjadi good product. Ada beberapa kategori ban hasil produksi, yakni sebagi berikut:

a. Kategori OE

OEM (Original Equipment Manufacture) adalah ban yang dibuat untuk perakitan atau dikirim langsung kepabrik mobil atau Agen Tunggal Pemegang Merek (ATPM) atau dealer mobil.

\section{b. Kategori OK}

kategori ban OK merupakan kategori dimana ban tersebut secara level nilai dynamic balance dan uniformity berada diatas ban berkategori OE. Ban dengan kategori OK didistribusikan ke market seperti Tire Zone sebagai ban replacement.

c. Kategori NG

kategori ban NG (Not Good) adalah ban yang tidak memenuhi standart ban berkategori OE dan OK. Apabila masih dapat ditoleransi, diperbolehkan untuk dilakukan repair.

\subsubsection{UML (Unified Modelling Language)}

Unified Modeling Language (UML) adalah bahasa spesifikasi standar yang dipergunakan untuk mendokumentasikan, menspesifikasikan dan membanngun perangkat lunak [7]. UML merupakan metodologi dalam mengembangkan sistem berorientasi objek dan juga merupakan alat untuk mendukung pengembangan sistem UML juga menjadi salah satu cara untuk mempermudah pengembangan aplikasi yang berkelanjutan. Aplikasi atau sistem yang tidak terdokumentasi biasanya dapat menghambat pengembangan karena developer harus melakukan penelusuran dan mempelajari kode program. UML merupakan bahasa standar yang digunakan untuk menjelaskan dan menvisualisasikan artifak dari proses analisa dan desain berorientasi objek. UML menyediakan standar pada notasi dan diagram yang dapat digunakan untuk memodelkan sistem. UML menjadi bahasa yang dapat digunakan untuk berkomunikasi dalam perspektif objek antara user dengan developer, developer dengan developer desain, dan developer pemrograman. Pemodelan visual membantu untuk menangkap struktur dan kelakuan dari objek, mempermudah penggambaran interaksi antara elemen dalam sistem, dan mempertahankan konsistensi antara desain dan implementasi dalam pemrograman.

\subsubsection{Visual Basic.Net 2013}

Visual Studio 2013 merupakan perangkat lunak untuk mengembangkan applikasi yang dikembangkan oleh microsoft [8].Microsoft Visual Studio adalah sebuah Integrated Development Environment buatan Microsoft Coroporation. Microsoft Visual Studio dapat digunakan untuk mengembangkan aplikasi dalam native code (dalam bentuk bahasa mesin yang berjalan di atas Windows) ataupun managed code (dalam bentuk Microsoft Intermediate Language di atas .NET Framework). Selain itu, Visual Studio juga dapat digunakan untuk mengembangkan aplikasi Silverlight, aplikasi Windows Mobile (yang berjalan di atas .NET Compact Framework). Visual Basic mencakup sebuah kode editor yang didukung oleh fitur intellisense atau yang disebut dengan code refactoring. Debugger telah terintegrasi bekerja pada level source level debugger dan level debugger mesin [9].

\subsubsection{Xampp}

XAMPP adalah sebuah software web server apache yang didalamnya sudah tersedia database server MySQL dan dapat mendukung pemrograman PHP. XAMPP merupakan software yang mudah digunakan, gratis dan mendukung instalasi di Linux dan Windows. Nama 
XAMPP adalah suatu singkatan dari X yakni 4 buah sistem operasi berupa Perl, PHP, MySQL, dan Apache [10]. XAMPP juga dapat diibaratkan sebagai software yang menjembatani anatara aplikasi yang akan dibuat dengan sistem database MySQL.

\section{HASIL DAN PEMBAHASAN}

Sistem yang dirancang dan dibuat lebih memudahkan penggunanya, selain itu fitur yang disematkan pada sistem aplikasi Monitorig Tyre ini juga beragam. Terdapat 3 buah halaman yang mampu mempermudah inspektor dan admin dalam melakukan pemantauan. Yakni halaman Monitoring Tyre, halaman Performance Inspector, dan Halaman History Karantina. Pada halaman-halaman terebut juga disematkan fitur pencarian data serta fitur export data to excel yang akan mempermudah penggunanya dalam proses pembuatan report.

\subsection{Use Case Diagram}

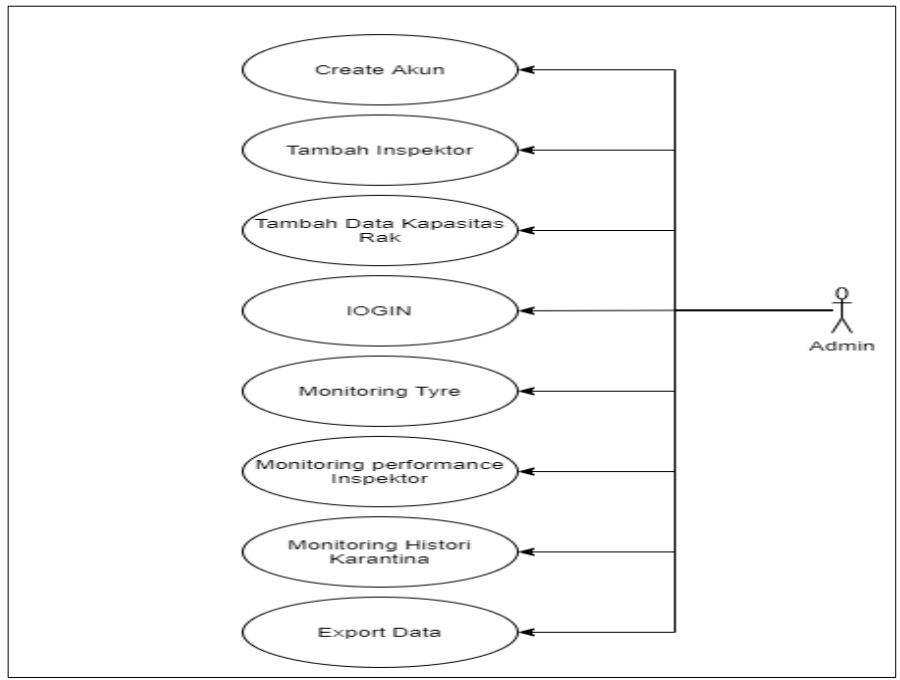

Gambar 4. Use Case Diagram

Berdasarkan gambar diatas diagram use case tersebut dapat dijabarkan sebagai berikut:

1. Admin sebagai user sistem dapat melakukan registrasi atau pembuatan akun baru.

2. Admin sebagai user sistem dapat melakukan registrasi atau penambahan data inspektor.

3. Admin sebagai user sistem dapat melakukan registrasi atau penambahan data kapasitas rak.

4. Admin sebagai user sistem dapat melakukan Login pada aplikasi Monitoring Tyre.

5. Admin sebagai user sistem dapat melakukan monitoring tyre di halaman Monitoring Tyre.

6. Admin sebagai user sistem dapat melakukan pemantauan performance inspector di halaman Performance Inspector.

7. Admin sebagai user sistem dapat melakukan pemantauan ban yang sudah dilakukan scan di halaman History Karantina.

8. Admin sebagai user sistem dapat melakukan export data untuk pembuatan laporan. 
2.2 Activity Diagram

3.2.1 Activity Diagram Login Aplikasi Monitoring Tyre

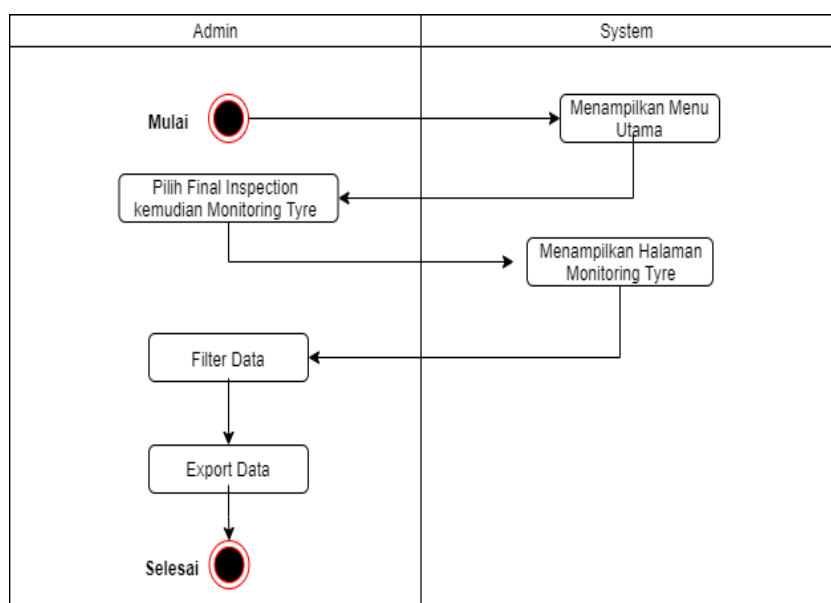

Gambar 5. Activity Diagram Login Aplikasi Monitoring Tyre

3.2.2. Activity Diagram Monitoring Tyre

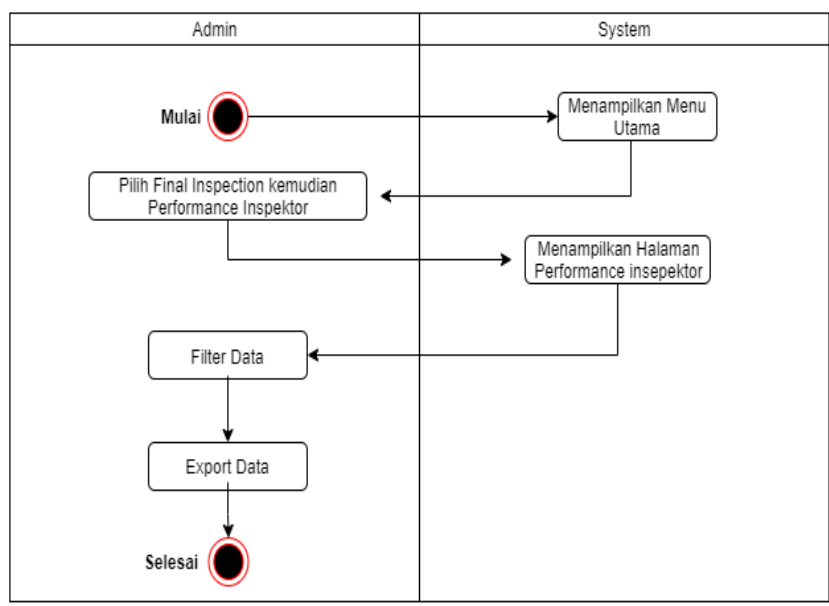

Gambar 6. Activity Diagram Monitoring Tyre

3.2.3 Activity Diagram Performance Inspector

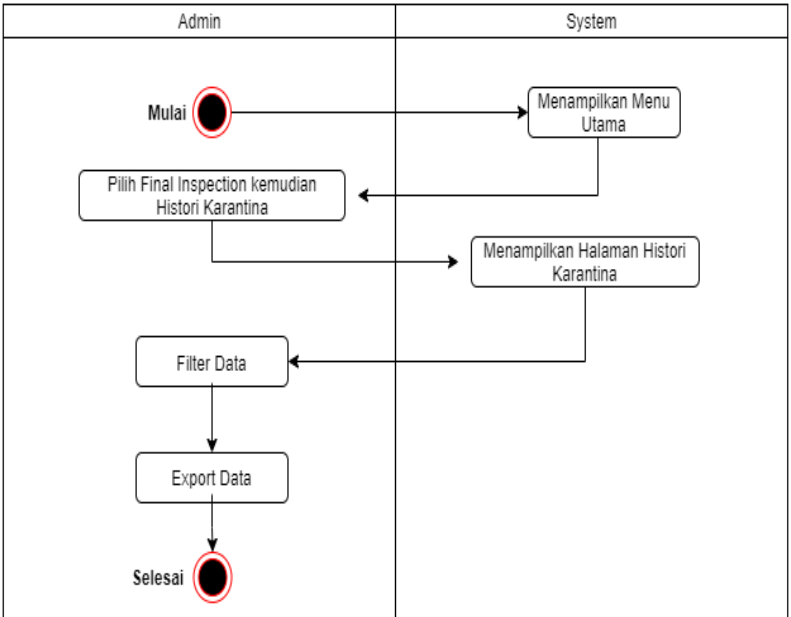

Gambar 7. Activity Diagram Performance Inspector 


\subsection{Sequence Diagram}

3.3.1 Sequence Diagram Monitoring Tyre

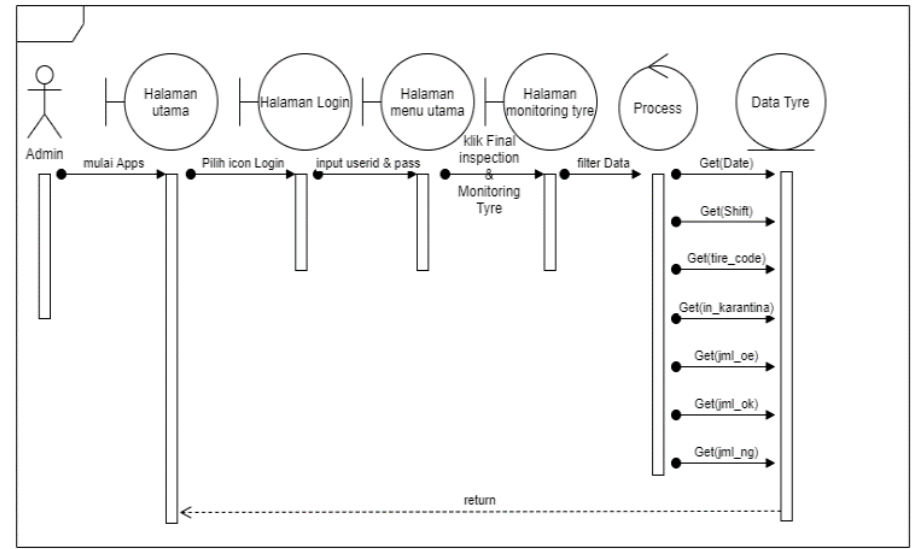

Gambar 8. Sequence Diagram Monitoring Tyre

\subsubsection{Sequence Diagram Performance Inspector}

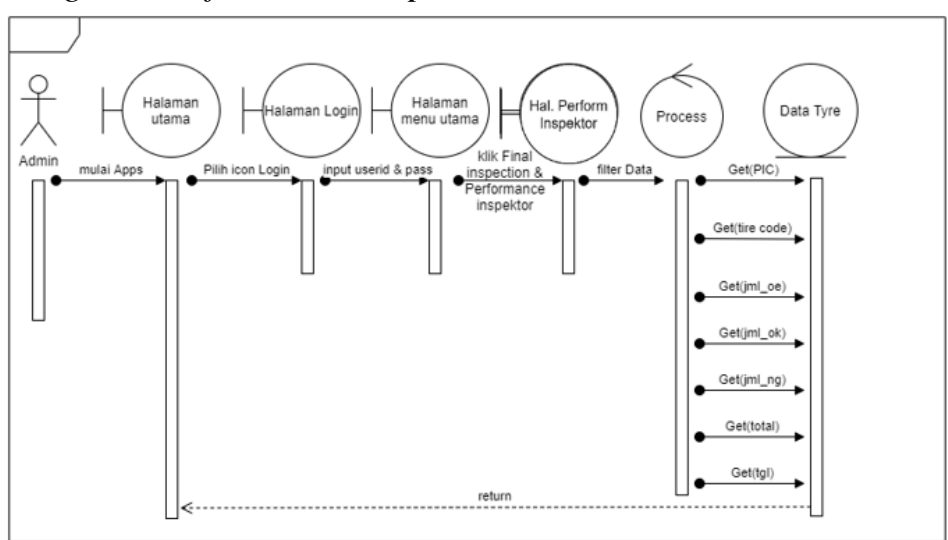

Gambar 9. Sequence Diagram Performance Inspector

3.3.3 Sequence Diagram History Karantina

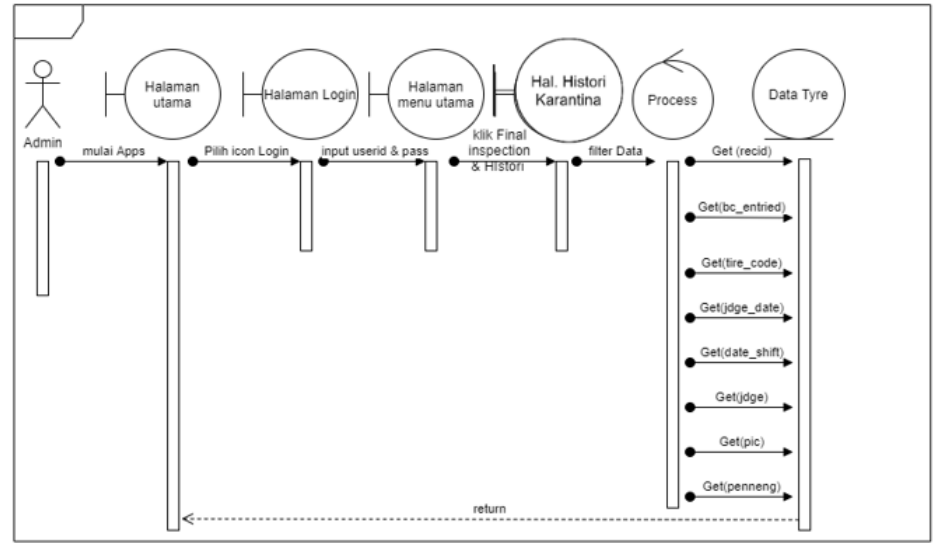

Gambar 10. Sequence Diagram History Karantina 


\subsection{Class Diagram}

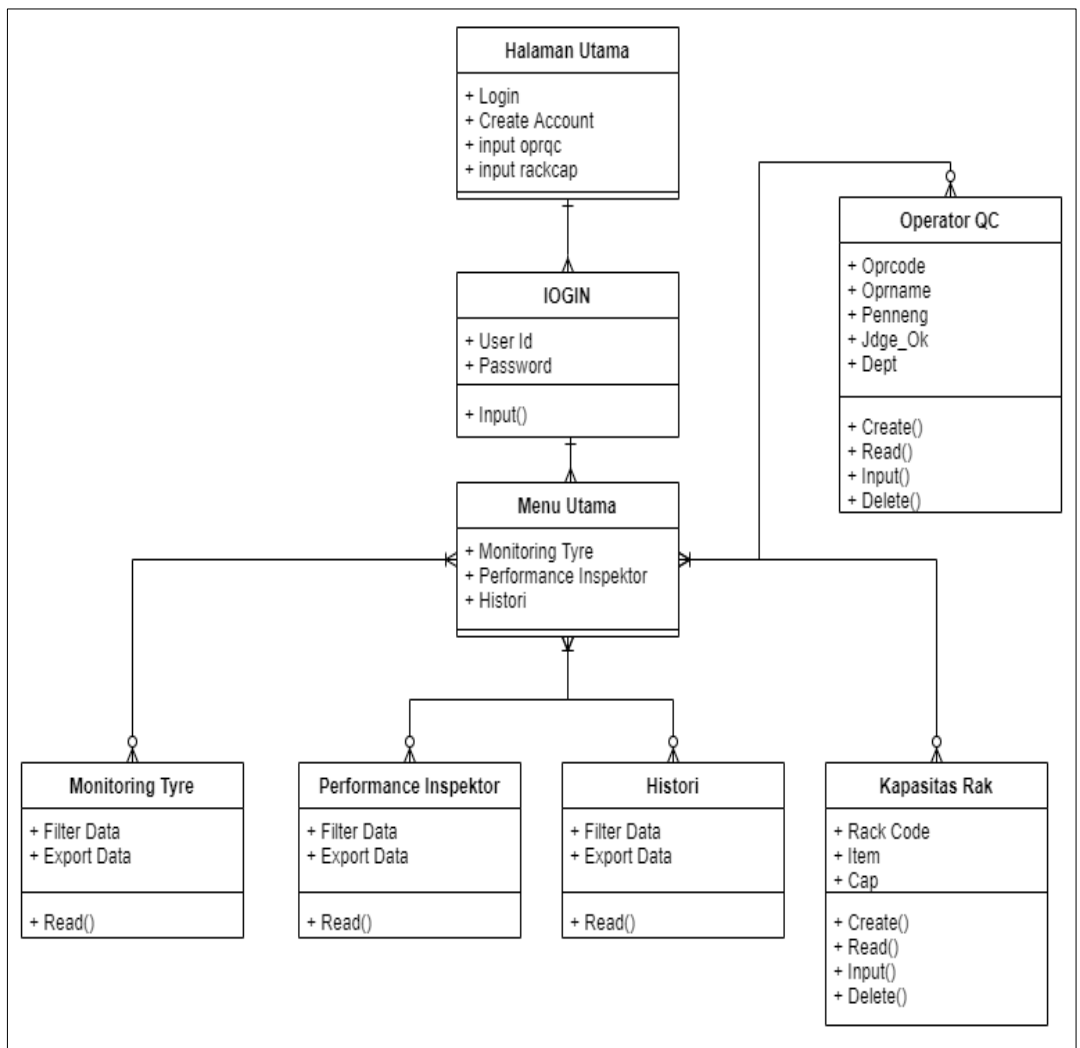

Gambar 10. Class Diagram Aplikasi Monitoring Tyre

\subsection{Implementasi Program}

\subsubsection{Tampilan Halaman Awal}

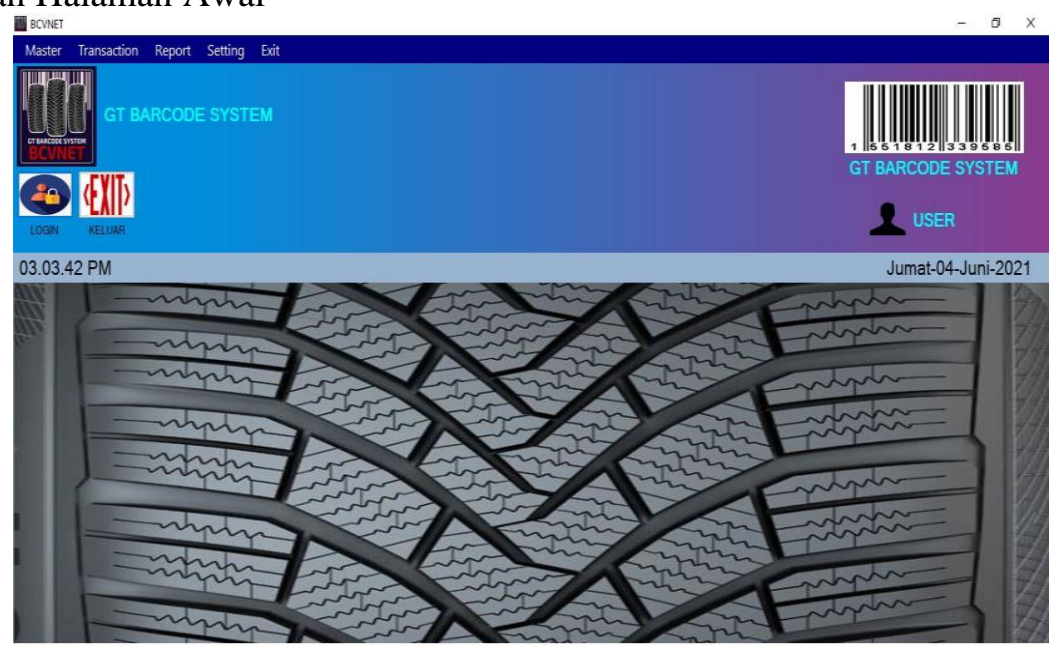

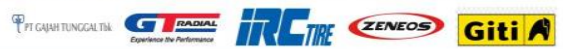

Gambar 11. Tampilan Halaman Awal

Gambar diatas merupakan tampilan awal saat aplikasi dijalankan. Pada tampilan awal apabila akan melakukan login disediakan tombol login untuk memunculkan form login. Apabila ingin membuat akun baru untuk melakukan login maka klik menu master pada menu bar.

\subsubsection{Tampilan Login}




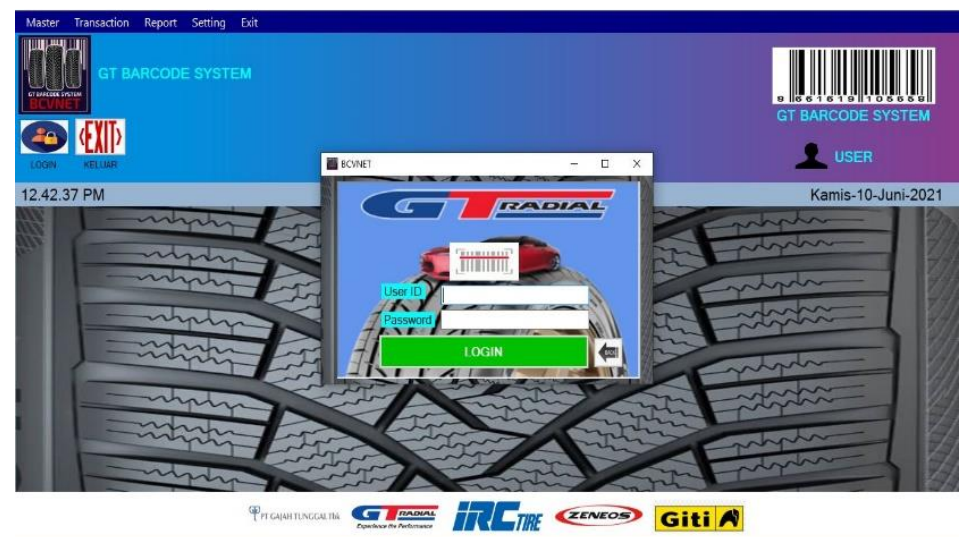

Gambar 12. Tampilan Halaman Login

Gambar diatas merupakan tampilan form login. Untuk mengakses aplikasi monitoring tyre user diminta untuk memasukkan user id dan password yang telah terdaftar.

3.4.3 Tampilan Menu Utama

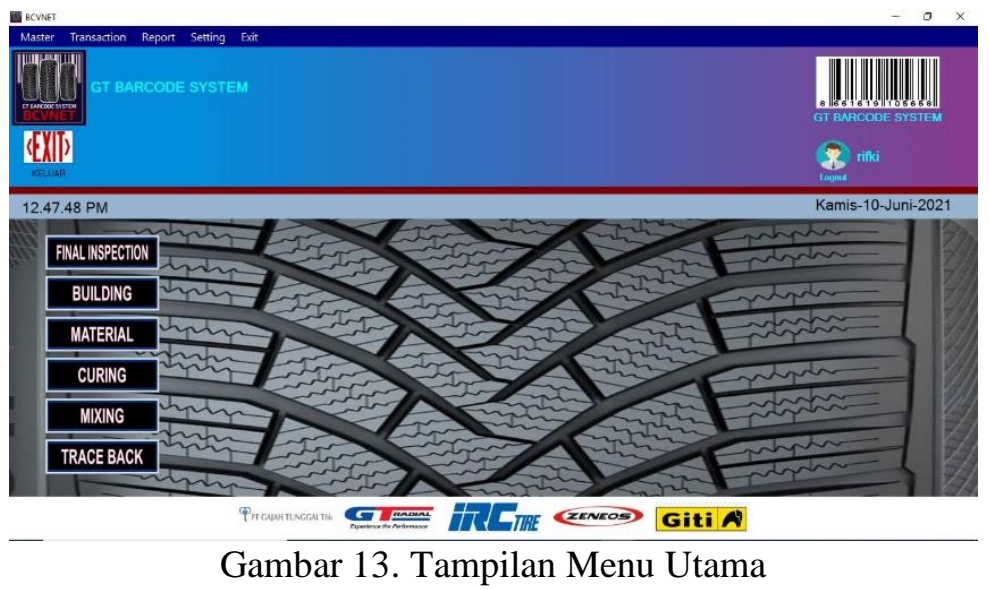

Gambar diatas merupakan tampilan form login. Untuk mengakses aplikasi monitoring tyre user diminta untuk memasukkan user id dan password yang telah terdaftar.

\subsubsection{Tampilan Halaman Monitoring Tyre}

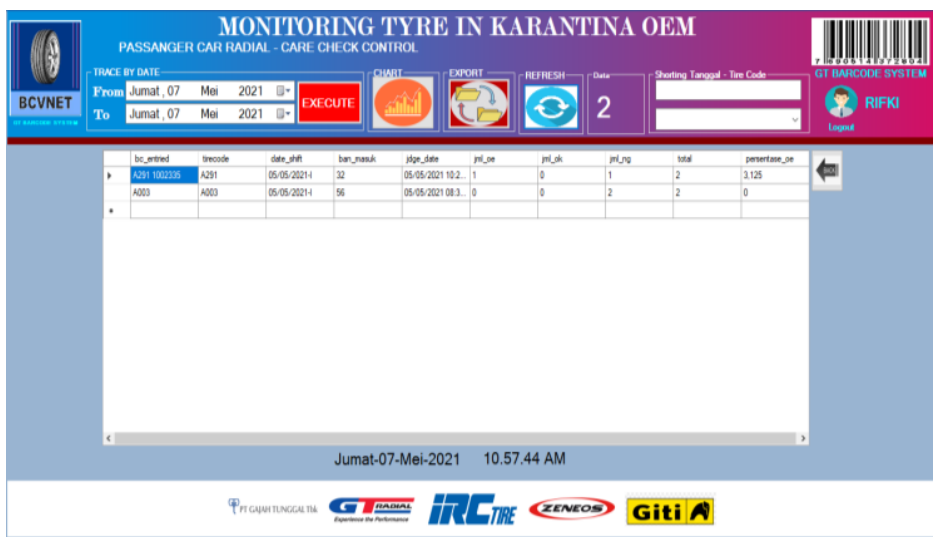

Gambar 14. Tampilan Halaman Monitoring Tyre

Gambar diatas merupakan tampilan halaman menu utama. Halaman utama 
muncul apabila user berhasil melakukan login dengan user id dan password yang benar. Pada menu utama untuk menuju halaman monitoring tyre, performance inspektor, dan history karantina dapat menekan tombol Final inspection dan memilih menu yang muncul.

\subsubsection{Tampilan Halaman Performance Inspector}

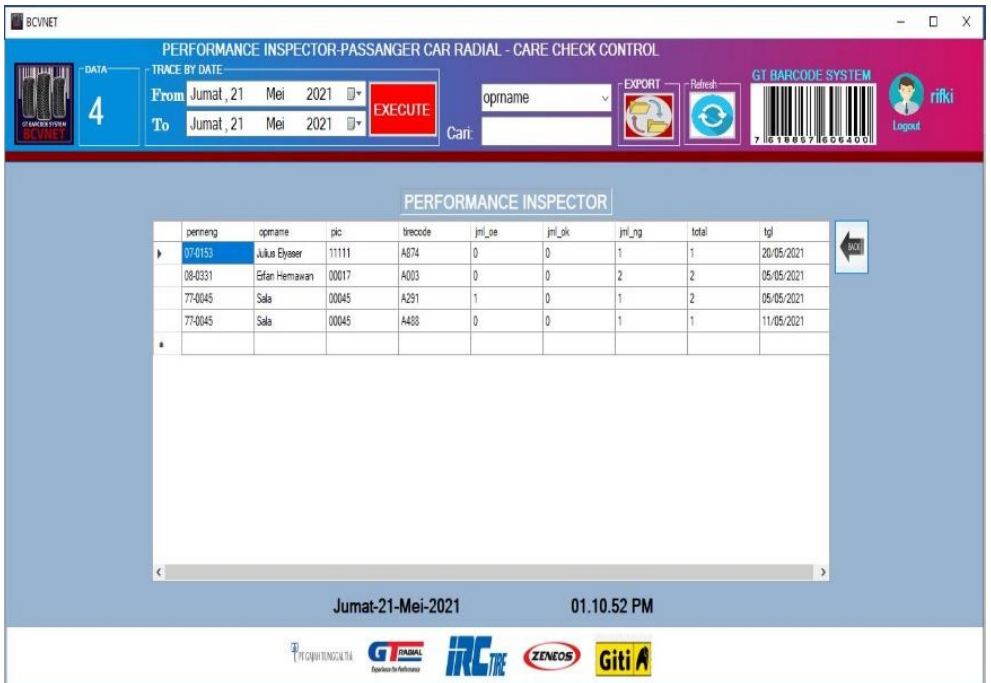

Gambar 15. Tampilan Halaman Perfromance Inspector

Gambar diatas merupakan halaman performance inspektor. Dimana pada halaman tersebut memuat data jumlah ban yang dicek oleh inspektor di area Karantina OEM. Data tersebut terhimpun per tanggal. Sehingga dikemudian hari dapat dilakukan rekap performance inspektor dalam tenggang periode teretntu.

\subsubsection{Tampilan Halaman Operator QC}

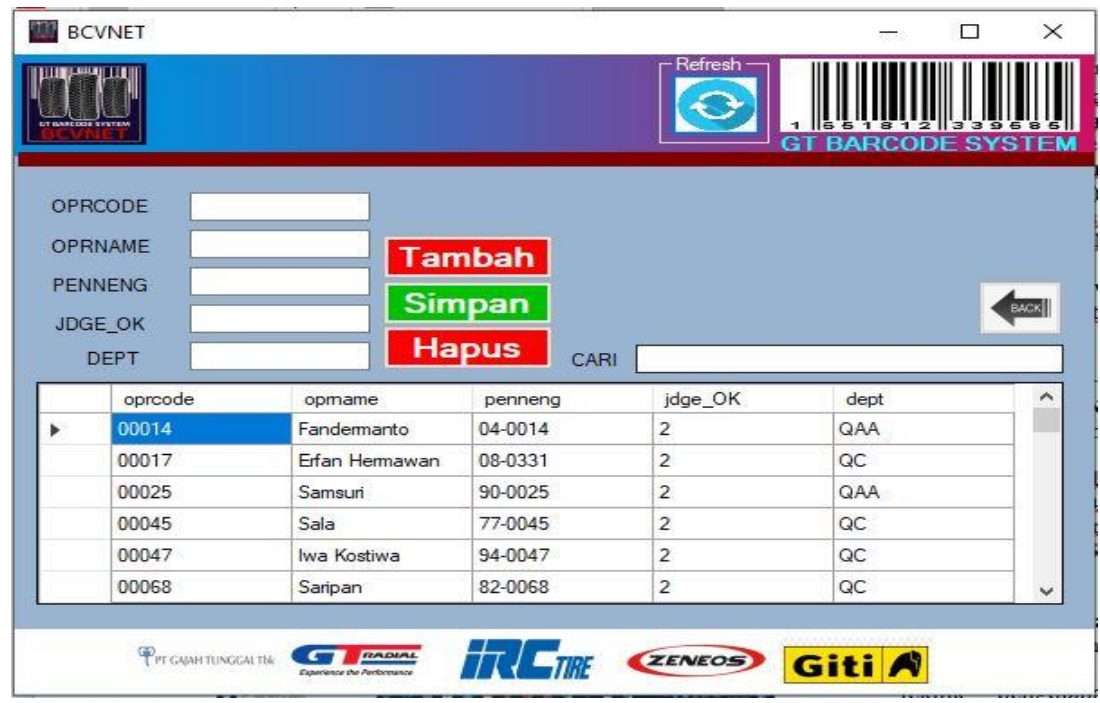

Gambar 16. Tampilan Halaman Operator QC

Gambar diatas merupakan tampilan halaman operator QC. Fungsi dari pada halaman ini yakni mendaftarakan akun inspektor agar dapat melakukan scan di scanner 
pada PDT. Data yang telah terdaftar akan disimpan pada database tabel oprqc.

3.4.7 Tampilan Halaman Kapasitas Rak

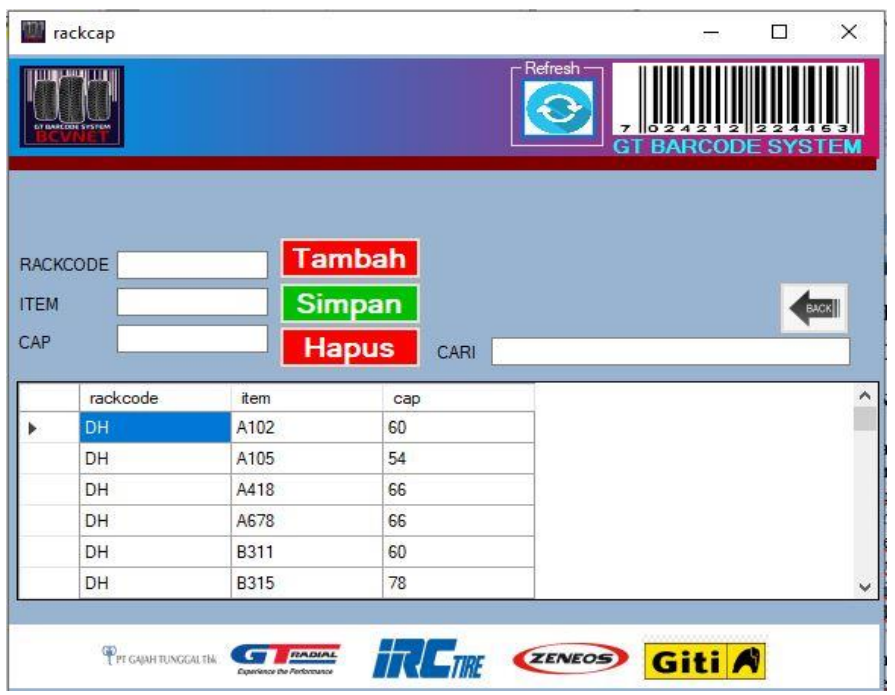

Gambar 17. Tampilan Halaman Kapasitas Rak

Gambar diatas merupakan tampilan halaman kapasitas rak. Fungsi dari pada halaman ini yakni mendaftarakan size ban yang dapat di scan pada opsi nomor 4 aplikasi scanner. Data yang telah terdaftar akan disimpan pada database tabel rackcap.

3.5 Verifikasi dan Validasi Sistem

Tabel 1. Verifikasi dan validasi sistem

\begin{tabular}{|c|c|c|c|c|c|c|}
\hline \multirow[t]{2}{*}{ No } & \multirow[t]{2}{*}{ Halaman } & \multirow[t]{2}{*}{ Pengujian } & \multicolumn{2}{|c|}{ Hasil } & \multirow{2}{*}{$\begin{array}{c}\text { AVG } \\
\text { Interval } \\
\text { waktu }\end{array}$} & \multirow[t]{2}{*}{$\%$} \\
\hline & & & Berhasil & failed & & \\
\hline \multirow[t]{2}{*}{1} & \multirow[t]{2}{*}{ Login } & $\begin{array}{l}\text { Membuka } \\
\text { halaman }\end{array}$ & $5 X$ & 0 & 1,28 detik & $100 \%$ \\
\hline & & Proses Login & $5 X$ & 0 & 1,2 detik & $100 \%$ \\
\hline \multirow[t]{4}{*}{2} & \multirow[t]{4}{*}{ Create Akun } & $\begin{array}{l}\text { Membuka } \\
\text { Halaman }\end{array}$ & $5 X$ & 0 & 1,2 detik & $100 \%$ \\
\hline & & $\begin{array}{l}\text { Membuat } \\
\text { Akun }\end{array}$ & $5 X$ & 0 & 6,8 detik & $100 \%$ \\
\hline & & $\begin{array}{l}\text { Menghapus } \\
\text { Akun }\end{array}$ & $5 X$ & 0 & 1,3 detik & $100 \%$ \\
\hline & & $\begin{array}{l}\text { Menutup } \\
\text { Halaman }\end{array}$ & $5 X$ & 0 & 1,2 detik & $100 \%$ \\
\hline \multirow[t]{5}{*}{3} & \multirow[t]{5}{*}{ oprqc } & $\begin{array}{l}\text { Membuka } \\
\text { Halaman }\end{array}$ & $5 X$ & 0 & 1,2 detik & $100 \%$ \\
\hline & & $\begin{array}{l}\text { Menampilkan } \\
\text { Data }\end{array}$ & $5 X$ & 0 & 1,3 detik & $100 \%$ \\
\hline & & $\begin{array}{l}\text { Menyimpan } \\
\text { Data }\end{array}$ & $5 X$ & 0 & 1,8 detik & $100 \%$ \\
\hline & & $\begin{array}{l}\text { Menghapus } \\
\text { Data }\end{array}$ & $5 X$ & 0 & 1,3 detik & $100 \%$ \\
\hline & & $\begin{array}{l}\text { Memfilter } \\
\text { Data }\end{array}$ & $5 X$ & 0 & 1,4 detik & $100 \%$ \\
\hline
\end{tabular}


ISSN : $2356-5195$

Online ISSN: 2654 - 8704

\begin{tabular}{|c|c|c|c|c|c|c|}
\hline \multirow[t]{5}{*}{4} & \multirow[t]{5}{*}{ rackcap } & $\begin{array}{l}\text { Membuka } \\
\text { Halaman }\end{array}$ & $5 X$ & 0 & 1,2 detik & $100 \%$ \\
\hline & & $\begin{array}{l}\text { Menampilkan } \\
\text { Data }\end{array}$ & $5 X$ & 0 & 1,3 detik & $100 \%$ \\
\hline & & $\begin{array}{l}\text { Menyimpan } \\
\text { Data }\end{array}$ & $5 X$ & 0 & 1,6 detik & $100 \%$ \\
\hline & & $\begin{array}{l}\text { Menghapus } \\
\text { Data }\end{array}$ & $5 X$ & 0 & 1,3 detik & $100 \%$ \\
\hline & & $\begin{array}{l}\text { Memfilter } \\
\text { Data }\end{array}$ & $5 X$ & 0 & 1,4 detik & $100 \%$ \\
\hline \multirow[t]{5}{*}{5} & \multirow[t]{5}{*}{$\begin{array}{c}\text { Monitoring } \\
\text { Tyre }\end{array}$} & $\begin{array}{l}\text { Membuka } \\
\text { Halaman }\end{array}$ & $5 X$ & 0 & 1,2 detik & $100 \%$ \\
\hline & & $\begin{array}{l}\text { Menampilkan } \\
\text { Data }\end{array}$ & $5 X$ & 0 & 1,04 detik & $100 \%$ \\
\hline & & $\begin{array}{l}\text { Memfilter } \\
\text { Data }\end{array}$ & $5 X$ & 0 & 1,45 detik & $100 \%$ \\
\hline & & Export Data & $5 X$ & 0 & $\begin{array}{c}59,0 \\
\text { detik/1000 } \\
\text { data }\end{array}$ & $100 \%$ \\
\hline & & $\begin{array}{l}\text { Menutup } \\
\text { Halaman }\end{array}$ & $5 X$ & 0 & 1,2 detik & $100 \%$ \\
\hline \multirow[t]{5}{*}{6} & \multirow[t]{5}{*}{$\begin{array}{l}\text { Performance } \\
\text { Inspector }\end{array}$} & $\begin{array}{l}\text { Membuka } \\
\text { Halaman }\end{array}$ & $5 X$ & 0 & 1,2 detik & $100 \%$ \\
\hline & & $\begin{array}{l}\text { Menampilkan } \\
\text { Data }\end{array}$ & $5 X$ & 0 & 1,2 detik & $100 \%$ \\
\hline & & $\begin{array}{l}\text { Memfilter } \\
\text { Data }\end{array}$ & $5 X$ & 0 & 1,33 detik & $100 \%$ \\
\hline & & Export Data & $5 X$ & 0 & $\begin{array}{c}59,0 \\
\text { detik/1000 } \\
\text { data }\end{array}$ & $100 \%$ \\
\hline & & $\begin{array}{l}\text { Menutup } \\
\text { Halaman }\end{array}$ & $5 X$ & 0 & 1,2 detik & $100 \%$ \\
\hline \multirow[t]{5}{*}{7} & \multirow[t]{5}{*}{$\begin{array}{c}\text { Histori } \\
\text { Karantina }\end{array}$} & $\begin{array}{l}\text { Membuka } \\
\text { Halaman }\end{array}$ & $5 X$ & 0 & 1,2 detik & $100 \%$ \\
\hline & & $\begin{array}{l}\text { Menampilkan } \\
\text { Data }\end{array}$ & $5 X$ & 0 & 1,5 detik & $100 \%$ \\
\hline & & $\begin{array}{l}\text { Memfilter } \\
\text { Data }\end{array}$ & $5 X$ & 0 & 1,3 detik & $100 \%$ \\
\hline & & Export Data & $5 X$ & 0 & $\begin{array}{c}59,0 \\
\text { detik/1000 } \\
\text { data }\end{array}$ & $100 \%$ \\
\hline & & $\begin{array}{l}\text { Menutup } \\
\text { Halaman }\end{array}$ & $5 X$ & 0 & 1,2 detik & $100 \%$ \\
\hline
\end{tabular}

\section{KESIMPULAN}

\subsection{Kesimpulan}

Sistem aplikasi Monitoring Tyre yang dibuat pada penelelian ini dapat berfungsi dengan baik. Apabila dilihat dari uji validasi dan verifikasi yang telah dilaksanakan setiap fiturnya juga dapat berfungsi dengan baik. Dengan aplikasi ini admin di departemen Final Inspection khususnya section area Original Equipment Manufature (OEM) dapat lebih mudah memproses report hasil check dengan tahapan pemrosesan data yang lebih singkat yakni 5 step dan hanya 
membutuhkan waktu 5-7 menit saja. Serta inspektor juga dapat melakukan monitoring jumlah ban yang masuk di area karantina OEM dengan mudah melalui aplikasi monitoring tyre.

\section{SARAN}

\subsection{Saran}

Pada sistem yang telah dibuat pada penelitian ini belum memiliki fitur update data pada menu di halaman operator QC dan halaman Kapasitas rak. Fitur update tersebut berguna apabila user dari aplikasi ingin melakukan pembaharuan data atau mengganti data yang sudah terdaftar. Maka lebih baik pada sebuah sistem yang didalamnya memuat aktivitas registrasi data dibekali dengan fitur update data.

\section{DAFTAR PUSTAKA}

[1] B. Robby Sagita, "Rancang Bangun Prototype Sistem Monitoring Level Air Untuk Mendeteksi Banjir Berbasis Mikrokontroler Arduino Dan Visual Basic.Net," J. Manaj. Inform., vol. 8, no. 2, pp. 98-104, 2018.

[2] A. Triwiyatno, "Lampiran D Perancangan Sistem Monitoring Suhu Dan Kadar Air Pakan Visual Studio."

[3] Samsir, "Rancang Bangun Palikasi Suku Cadang Pada Toko Urip Motor Menggunakan VB.NET 2010," J. Comput. Sci. Inf., vol. 1, no. 1, pp. 13-18, 2020, [Online]. Available: http://jurnal.ulb.ac.id/index..php/JCoInS/index.

[4] R. E. Putri and R. R. Putra, "Perancangan Aplikasi Rekam Medis Menggunakan Bahasa Pemograman VB.Net 2010,” J. Tek. dan Inform., vol. 5, no. 2, pp. 49-55, 2018.

[5] I. F. Mukhlis, "Rancang Bangun Penilaian Barang Bergerak Pada Kantor Pt . Mandiri Finance Menggunakan Visual Studio 2010,” vol. XV, pp. 68-74, 2020.

[6] A. H. Khatimah, "Rancang Bangun Aplikasi Monitoring Pada Kegiatan Mentoring," Skripsi, 2017.

[7] Suendri, "Implementasi Diagram UML (Unified Modelling Language) Pada Perancangan Sistem Informasi Remunerasi Dosen Dengan Database Oracle (Studi Kasus: UIN Sumatera Utara Medan)," J. Ilmu Komput. dan Inform., vol. 3, no. 1, pp. 19, 2018, [Online]. Available: http://jurnal.uinsu.ac.id/index.php/algoritma/article/download/3148/1871.

[8] M. Vivi, "Rancang Bangun Aplikasi Sistem Pendataan Akademik SMP Negeri 4 Malengke Barat Berbasis Visual Studio," 2020.

[9] N. E. Putri and S. Azpar, "Jurnal Edik Informatika Sistem Informasi Pengolahan Data Pendidikan Anak Usia Dini ( PAUD ) Terpadu Amalia Syukra Padang Jurnal Edik Informatika," Sist. Inf. Pengolah. Data Pendidik. Anak Usia Dini Terpadu Amalia Syukra Padang, pp. 203-212, 2016.

[10] H. Riyadli, A. Arliyana, and F. E. Saputra, "Rancang Bangun Sistem Informasi Keuangan Berbasis WEB," J. Sains Komput. dan Teknol. Inf., vol. 3, no. 1, pp. 98-103, 2020, doi: 10.33084/jsakti.v3i1.1770. 